\title{
The Interferon (IFN) Class of Cytokines and the IFN Regulatory Factor (IRF) Transcription Factor Family
}

\author{
Hideo Negishi, ${ }^{1}$ Tadatsugu Taniguchi, ${ }^{1,2}$ and Hideyuki Yanai ${ }^{1,2}$ \\ ${ }^{1}$ Department of Molecular Immunology, Institute of Industrial Science, The University of Tokyo, Komaba 4-6-1, \\ Meguro-ku, Tokyo 153-8505, Japan \\ ${ }^{2}$ Max Planck-The University of Tokyo Center for Integrative Inflammology, Komaba 4-6-1, Meguro-ku, Tokyo \\ 153-8505, Japan \\ Correspondence: tada@m.u-tokyo.ac.jp
}

\begin{abstract}
Interferons (IFNs) are a broad class of cytokines elicited on challenge to the host defense and are essential for mobilizing immune responses to pathogens. Divided into three classes, type I, type II, and type III, all IFNs share in common the ability to evoke antiviral activities initiated by the interaction with their cognate receptors. The nine-member IFN regulatory factor (IRF) family, first discovered in the context of transcriptional regulation of type I IFN genes following viral infection, are pivotal for the regulation of the IFN responses. In this review, we briefly describe cardinal features of the three types of IFNs and then focus on the role of the IRF family members in the regulation of each IFN system.
\end{abstract}

\begin{abstract}
$A^{11}$ three classes of interferons (IFNs) are so Anamed because of the shared property to interfere with viral replication in the host (Weissmann and Weber 1986; Taniguchi 1988; Stark et al. 1998; Levy and Garcia-Sastre 2001; Samuel 2001; Katze et al. 2002; Pestka et al. 2004; Platanias 2005; Vilcek 2006). It is perhaps not an exaggeration to say that the discovery of IFNs provided the biggest impetus for the study of all cytokine research. Type I IFNs were initially discovered as soluble factors that mediated viral interference. This is defined as the resistance to virus infection induced by a prior viral infection (Isaacs and Lindenmann 1957; Nagano and Kojima 1958). It was not until after two decades of study that type I IFN genes were cloned, se-
\end{abstract}

quenced, and formally recognized to comprise a related gene family (Knight 1975; Taniguchi et al. 1979; Maeda et al. 1980; Rubinstein et al. 1981; Weissmann and Weber 1986; Taniguchi 1988; Stark et al. 1998; Levy and Garcia-Sastre 2001; Samuel 2001; Katze et al. 2002; Pestka et al. 2004; Platanias 2005; Vilcek 2006). Type I IFNs are principally expressed by innate immune cells (Hervas-Stubbs et al. 2011). Type II IFN, represented by a single gene product, IFN- $\gamma$, was recognized for its antiviral activity induced by activated immune cells, typically by natural killer (NK) and T cells (Wheelock 1965; Gray et al. 1982). Type III IFNs (also called IFN- $\lambda$ and initially also called interleukin [IL]-28 and IL-29) are restricted in their tissue distribution (e.g., are

Editors: Warren J. Leonard and Robert D. Schreiber

Additional Perspectives on Cytokines available at www.cshperspectives.org

Copyright (C) 2018 Cold Spring Harbor Laboratory Press; all rights reserved; doi: 10.1101/cshperspect.a028423

Cite this article as Cold Spring Harb Perspect Biol 2018;10:a028423 
H. Negishi et al.

not highly expressed in hematopoietic cells), and act predominantly at epithelial surfaces (Sheppard et al. 2003; Iversen and Paludan 2010).

In this review, we first describe briefly the cardinal features of the three types of IFNs in the context of the signal transduction pathways they trigger and biological activities elicited and then focus on the regulation of these IFN responses by the IFN regulatory factor (IRF) transcription factor family. Of particular note, the discovery of so-called innate immune receptors beginning with Toll-like receptor 4 (Medzhitov et al. 1997) has provided the stimulus and context for understanding the regulatory mechanisms of IFNs by the IRF family transcription factors. Because of space limitations, we are unable to touch on various biological activities manifested by IFNs but instead point the reader to the many excellent reviews on the topic (Pestka et al. 2004; Vilcek 2006; Tamura et al. 2008; Trinchieri 2010).

\section{THREE TYPES OF IFNs: A BRIEF OVERVIEW}

The molecular characterization of IFNs began when type I IFN genes were recognized to comprise a gene family (Taniguchi et al. 1980; Pestka et al. 2004; Vilcek 2006). The two best-characterized and most broadly expressed genes of this subtype are IFN- $\alpha$, encoded by more than a dozen genes, and IFN- $\beta$ (single gene family) (Decker et al. 2005). Other type I IFN subtypes are known, namely, IFN- $\omega$, and IFN- $\tau$, but remain poorly characterized because of limited tissue expression, overlapping function with IFN- $\alpha$ and IFN- $\beta$, and species-to-species differences (Pestka et al. 2004; Capobianchi et al. 2015).

All type I IFN classes bind to a heterodimeric receptor composed of two chains, IFNAR1 and IFNAR2, which signal through recruitment of Janus-activated kinases (JAKs) TYK2 and JAK1, respectively (Fig. 1) (Taniguchi and Takaoka 2001; Pestka et al. 2004; Decker et al. 2005; Ivashkiv and Donlin 2014). Activation of these JAKs causes tyrosine phosphorylation of signal transducers and activators of transcription (STAT)1 and STAT2, which in turn leads to the formation of a trimeric complex, called
ISGF3 (IFN-stimulated gene [ISG] factor 3) that consists of STAT1, STAT2, and IRF9 (Taniguchi and Takaoka 2001; Pestka et al. 2004; Decker et al. 2005; Ivashkiv and Donlin 2014). ISGF3 is a transcriptional activator that on translocation to the nucleus binds IFN-stimulated response elements (ISREs) in gene promoters of IFN-inducible genes (ISGs) to initiate gene transcription. On the other hand, IRF2, localized in the nucleus, functions as a transcriptional attenuator of ISGF3-mediated transcriptional activation; hence, absence of IRF2 results in excessive type I IFN signaling (Hida et al. 2000). IFNAR activation also results in the activation of STAT1 homodimers that bind and activate $\gamma$ activated sequence (GAS) (IFN- $\gamma$ activated sequence) motifs, leading to the induction of gene transcription (Decker et al. 2005). Although less well characterized, type I IFN signaling may also induce signaling of mitogen-activated protein kinase (MAPK)/c-Jun amino-terminal kinase (JNK) pathways (Platanias 2005).

Type II IFN or IFN- $\gamma$ is structurally unrelated to the other two classes of IFN genes and is best known as a critical cytokine secreted during activated NK- and T-cell responses (Wheelock 1965; Gray et al. 1982). Further, IFN- $\gamma$ binds a different cell-surface receptor consisting of IFNGR1 and IFNGR2 subunits, which in turn associate with JAK1 and JAK2, respectively (Fig. 1). The activation of these kinases results in STAT1 homodimerization and nuclear translocation that targets GAS DNA sequences. It is worth noting that ISGF3 is also activated by the IFN- $\gamma$ signaling, albeit weakly (Takaoka et al. 2000). It was also shown that effective IFN- $\gamma$ signaling is contingent on a weak type I IFN signaling caused by a low constitutive production of type I IFNs (Takaoka et al. 2000).

Type III IFN or IFN- $\lambda$ s are the least characterized IFN family. Structurally related to type I IFNs and to the IL-10 family (Pestka et al. 2004; Uze and Monneron 2007; Lazear et al. 2015), this family includes IFN- $\lambda 1$ (IL-28A), IFN- $\lambda 2$ (IL-28B), and IFN- $\lambda 3$ (IL-29). IFN- $\lambda$ s bind to a heterodimeric cytokine receptor composed of an IL-28R-binding chain and IL-10R2 that is shared with the IL-10 family of cytokines (Fig. 1) (Uze and Monneron 2007). Similar to 
IFNs and the IRF Family

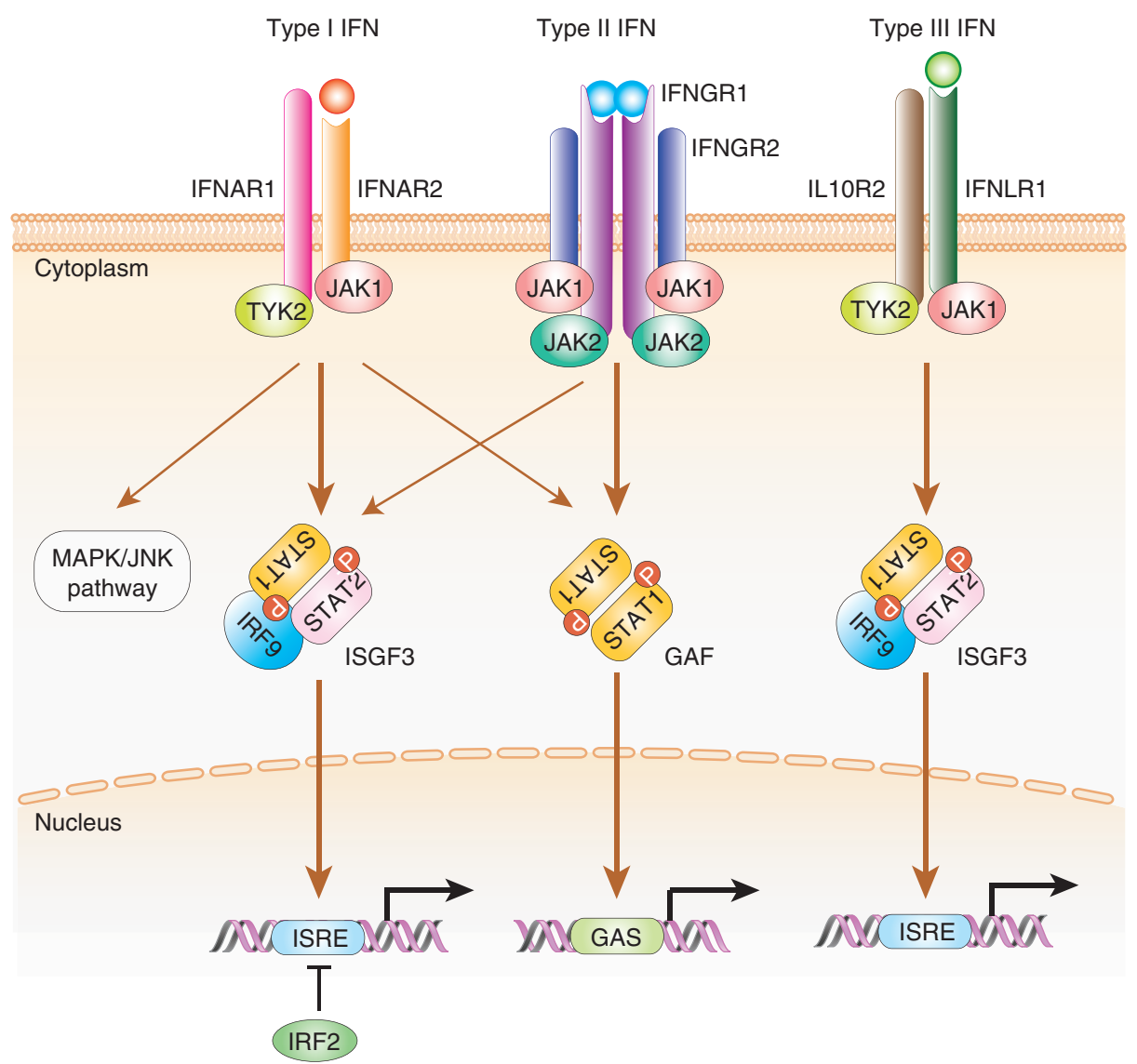

Figure 1. Signal transduction by type I, type II, and type III interferon (IFN) receptors. A schematic view of the signal transduction pathways for the three types of IFN is shown. Type I IFN binds IFNAR2, leading to the subsequent recruitment of IFNAR1. IFN- $\beta$ also forms a stable complex with IFNAR1 in an IFNAR2-indepenent manner, whereas IFN- $\alpha$ does not (de Weerd et al. 2013). The binding of type I IFN induces formation of a receptor complex between IFNAR-1 and IFNAR-2, leading to activation of the receptor-associated TYK2 and JAK1 kinases. This is followed by the tyrosine phosphorylation of signal transducers and activators of transcription (STAT)1 and STAT2 and, on recruitment of IFN regulatory factor (IRF)9, forms the heterotrimeric IFN-stimulated gene factor 3 (ISGF3) transcription factor complex. In addition, a STAT1 homodimer, termed IFN- $\gamma$-activated factor (GAF), is also formed. These transcriptional-activator complexes translocate into the nucleus and activate the IFN-stimulated regulatory elements (ISREs) or $\gamma$-activated sequences (GASs) promoter elements, for ISGF3, or GAF, respectively. IRF2 functions as a transcriptional attenuator of the ISGF3-mediated transcriptional activation. Type I IFN signaling may also induce signaling of mitogen-activated protein kinase (MAPK)/c-Jun amino-terminal kinase (JNK) pathways. Type II IFN binds as a homodimer and induces dimerization of IFNGR1 subunits and recruitment of IFNGR2 subunits. This association causes the phosphorylation of JAK1 and JAK2 kinases, leading to phosphorylation of STAT1. Phosphorylated STAT1 forms the GAF complex. IFN- $\gamma$ signaling also activates ISGF3, albeit weakly. Type III IFN receptor signaling cascade causes activation of JAK1 and TYK2, which causes the recruitment of STAT1 and STAT2 to form the ISGF3 transcription factor complex that binds to ISRE elements in gene promoters to induce transcription of IFN-inducible genes (ISGs). 
H. Negishi et al.

type I IFNs, the type III IFN receptor signaling cascade causes activation of JAK1 and TYK2 to cross-tyrosine phosphorylate the receptor complex, which causes the recruitment of STAT1 and STAT2 to form the ISGF3 transcription factor complex that activates ISGs (Uze and Monneron 2007; Lazear et al. 2015).

\section{THE IRF FAMILY TRANSCRIPTION FACTORS}

The IRF family of transcription factors is best known for its involvement in the regulation of gene expression that underlies IFN responses. Because there are available numerous review articles that describe in detail the function of each (Paun and Pitha 2007; Tamura et al. 2008; Yanai et al. 2012; Mancino and Natoli 2016), only the cardinal features of the IRF family are described in brief below. There are nine IRF proteins in mammals: IRF1, IRF2, IRF3, IRF4/PIP/LSIRF/ ICSAT, IRF5, IRF6, IRF7, IRF8/ICSBP, and IRF9/ISGF3 $\gamma$ (Paun and Pitha 2007; Tamura et al. 2008; Yanai et al. 2012; Mancino and Natoli 2016). In addition, IRF10 was found in birds and teleost fish but it is absent humans and mice (Suzuki et al. 2011).

All IRF proteins have a conserved aminoterminal DNA-binding domain (DBD) with a wing-type helix-loop-helix structure and a motif containing five regularly spaced tryptophan residues, which resemble the Myb DBD (Veals et al. 1992; Honda et al. 2006). The DBD recognizes a consensus DNA sequence element (A/ GNGAAANNGAAACT) (Tanaka et al. 1993), termed ISRE, which is found in the gene promoters of type I IFN, type III IFN, and ISG genes. The carboxy-terminal region of IRFs contains a conserved IRF-association domain (IAD) 1 or IAD2, which mediates homodimeric and heterodimeric intramolecular interactions with other IRF members, transcription factors, and/or cofactors (Takahasi et al. 2003).

\section{REGULATION OF THE TYPE I IFN SYSTEM BY IRFs}

Clearly, the IRF family members are best studied for their intimate critical involvement in type I IFN gene induction. Below, we summarize the current status of the IRF-mediated type I IFN gene induction by the activation of distinct types of innate pattern-recognition receptors, as well as IRF-mediated IFN responses.

Regulation of Type I IFNs by IRFs via Toll-Like Receptor (TLR) Signaling

TLRs were the first discovered pattern recognition receptors (PRRs) that recognize a variety of pathogen-associated molecular patterns (PAMPs) derived from pathogens to trigger the gene induction of type I IFNs and proinflammatory cytokines, resulting in the activation of immune responses (Medzhitov 2001; Kawai and Akira 2006). Thirteen TLR proteins (12 in mice and 10 in human) have been identified to date.

TLRs are localized to cell membranes on the cell surface or within endosomes. For instance, TLR3 is mainly localized to endosomes and recognizes double-stranded (ds)RNA derived from viruses or self-RNA derived from dead cells (Alexopoulou et al. 2001; Wang et al. 2004; Rudd et al. 2006), whereas TLR4 is located on the cell surface and recognizes a variety of PAMPs from bacteria or damage-associated molecular patterns (DAMPs) derived from dead cells (Kawai and Akira 2006; Andersson and Tracey 2011). Upon binding to cognate ligand, TLRs recruit adaptor proteins such as myeloid differentiation primary-response protein $88(\mathrm{MyD} 88)$ and/or Toll/interleukin-1 receptor (TIR) domain-containing adaptor, including IFN- $\beta$ (TRIF) to activate IRF proteins and other transcription factors. TLR3 and TLR4 induce type I IFN gene expression via signaling by TRIF-TANK (TNF receptor-associated factor [TRAF]-associated nuclear factor $[\mathrm{NF}]-\kappa \mathrm{B}$ activator)-binding kinase 1 (TBK1)-IRF3 (Fig. 2), albeit weakly as compared to retinoic acid-inducible gene I (RIG-I)-like receptors (RLRs) or stimulator of IFN genes (STING)-mediated induction (Negishi et al. 2012). Upon the recognition of their ligands, TRIF is phosphorylated and recruits downstream signaling molecules such as TRAF3, NAP1, and TBK1, resulting in the phosphorylation, dimerization, and nuclear translocation of IRF3 (Hemmi et al. 2004; McWhirter et al. 2004; Mori et al. 2004; Perry et al. 2004; Oganesyan 
IFNs and the IRF Family

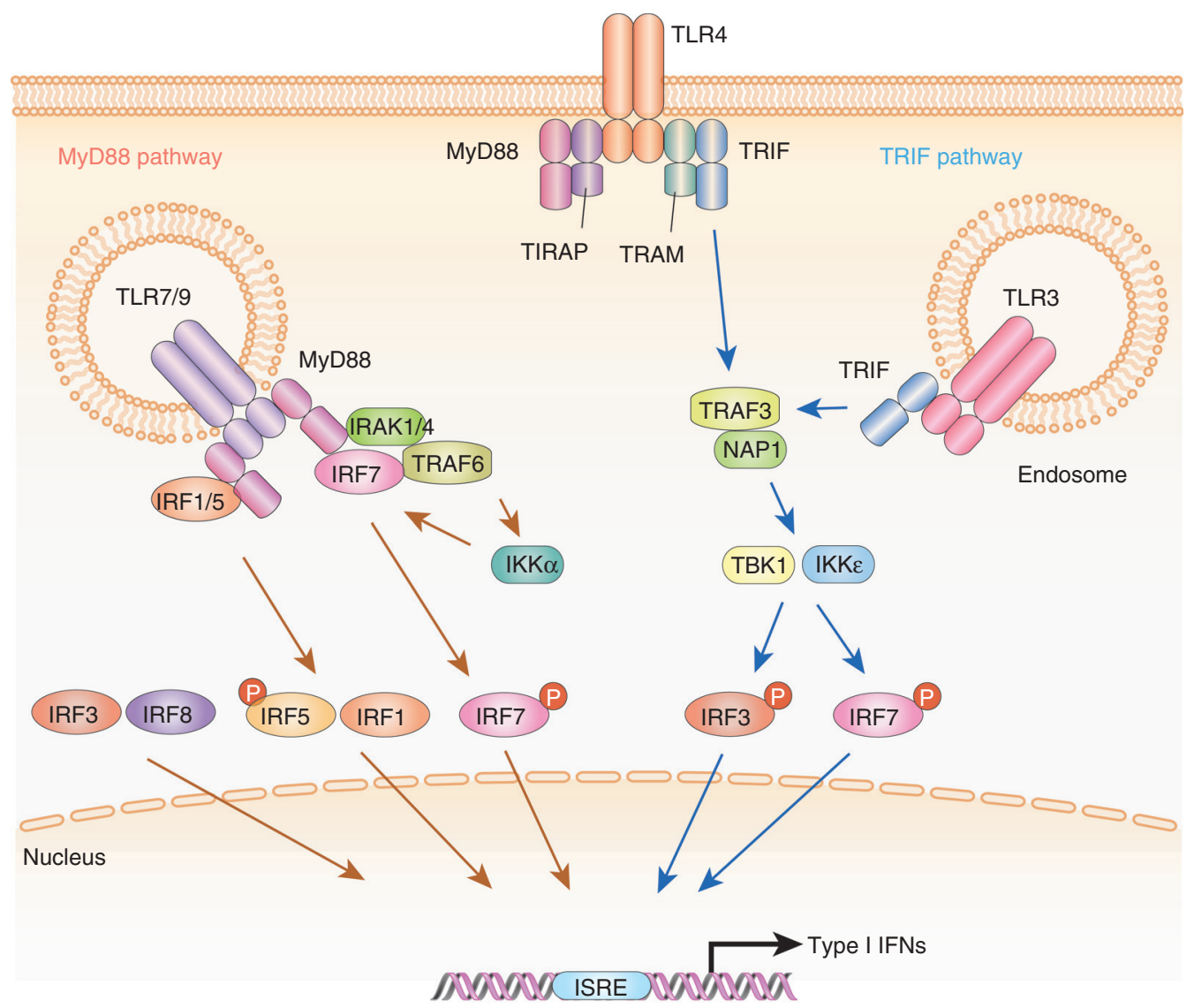

Figure 2. Schematic view of Toll-like receptor (TLR)-mediated type I interferon (IFN) gene induction by IFN regulatory factors (IRFs). The presence of RNA or double-stranded (ds)DNA in the cytosol triggers host responses via specific cytoplasmic pattern recognition receptors (PRRs). The binding of uncapped $5^{\prime}$-triphosphate RNA or dsRNA to the helicase domain of retinoic acid-inducible gene I (RIG-I)/melanoma differentiationassociated gene 5 (MDA5) induces the interaction between the caspase activation and recruitment domain (CARD) of RIG-I/MDA5 and the CARD-like domain of the adaptor mitochondrial antiviral signaling protein (MAVS), which is located on the mitochondrial membrane. This receptor-adaptor interaction results in the activation of tumor necrosis factor (TNF) receptor-associated factor (TRAF)-associated nuclear factor [NF]- $\mathrm{\kappa B}$ activator (TANK)-binding kinase 1 (TBK1) and inhibitor of NF- $\kappa B$ kinase (IKK) $\varepsilon$. Activated TBK1 induces the phosphorylation of the specific serine residues of IRF3 and IRF7. These IRFs then translocate into the nucleus and activate the type I IFN genes. NF- $\kappa \mathrm{B}$ is also activated and involved in type I IFN gene induction. In some cases, IRF5 or IRF8 participate in this IFN gene-induction pathway. dsDNA such as B-DNA is recognized by cGAS, IFI16, DDX41, and DAI. The stimulator of IFN genes (STING) adaptor protein on the endoplasmic reticulum membrane signals downstream of these DNA receptors. STING provides a scaffold for recruitment of TBK1, which phosphorylates IRF3 leading to the activation of type I IFN gene expression.

et al. 2006). Downstream of TLR4 signaling, IRF3 is critical for Ifnb gene induction, as expression was abolished in IRF3 knockout $\left(\operatorname{Irf3} 3^{-1-}\right)$ cells, but is essentially normal in $\operatorname{Irf} 7^{-1-}$ cells (Sakaguchi et al. 2003; Honda et al. 2005). On the other hand, both IRF3 and IRF7 are involved in TLR3-dependent type I IFN gene induction (Negishi et al. 2012).

Plasmacytoid dendritic cells (pDCs) are a subset of myeloid cells that express high amounts of TLR7 and TLR9 and secrete very high levels of type I IFNs (Colonna et al. 2004). TLR7 and 
H. Negishi et al.

TLR9 recognize single-stranded RNA (ssRNA) and nonmethylated CpG oligonucleotide DNA, respectively, to induce strong type I IFN responses (Colonna et al. 2004; Kawai and Akira 2006). In contrast to TLR3 and TLR4, TLR7- and TLR9-mediated type I IFN gene induction is entirely dependent on the MyD88 adaptor protein. Further, these receptors recruit IRF7, but not IRF3, downstream of MyD88 (Fig. 2) (Honda et al. 2004; Kawai et al. 2004) as type I IFN gene induction was completely abrogated in $\operatorname{Irf} 7^{-/-}$pDCs but normal in Irf3 $3^{-/-}$pDCs, following virus infection or treatment with synthetic ligands for TLR7 and TLR9 (Honda et al. 2005). However, in the case of a model of experimental Listeria monocytogenes infection in pDCs, evidence suggested that IRF3 was involved downstream of TLR9-mediated type I IFN gene induction, although the underlying molecular mechanism remains unclear (Stockinger et al. 2009). Also downstream of TLR7 and TLR9 signaling, MyD88 recruits interleukin 1 receptor associated kinase (IRAK) 1 and IRAK4 protein kinases, which are critical signal transducers required for the induction of type I IFN (Honda et al. 2004; Kawai and Akira 2006). The activation of IRAK kinases activates additional protein kinase cascades, including inhibitor of NF- $\kappa$ B kinase (IKK) $\alpha$, which is an essential kinase for the activation of IRF7 (Hoshino et al. 2006). MyD88 also recruits the adaptor protein TRAF6 (Kawai and Akira 2006). MyD88/ TRAF6-dependent K63-linked ubiquitination of IRF7 is also required for TLR-mediated type I IFN gene induction in pDCs (Kawai et al. 2004).

Like IRF7, IRF5 is also involved in TLR-dependent induction of type I IFNs via recruitment of MyD88, although the strength of the type I IFN induction is relatively weak as compared to IRF7 (Fig. 2) (Takaoka et al. 2005; Yasuda et al. 2013). In contrast, IRF5's main role following MyD88-dependent signaling is the induction of proinflammatory cytokine genes such as IL-12 $\beta$, IL-6, and TNF- $\alpha$ (Takaoka et al. 2005). Several regulatory mechanisms have been identified for modulating the TLR-dependent activation of IRF5. IKK $\beta$ phosphorylates and activates IRF5 in response to TLR stimulation (Balkhi et al. 2010; Bergstrøm et al. 2015).
TRAF6-mediated K63-linked ubiquitination is also required for IRF5 activation (Balkhi et al. 2008). In contrast, IKK $\alpha$-induced IRF5 phosphorylation inhibits IRF5 ubiquitination and attenuates its transcriptional activity (Balkhi et al. 2010). In addition, IRF4 negatively regulates IRF5 activation by competing with IRF5 for its interaction with the central region of MyD88 (Negishi et al. 2005). It has also been reported that Lyn, an Src family protein tyrosine kinase, interacts with IRF5 and suppresses its transcriptional activity by inhibiting phosphorylation and ubiquitination of IRF5 (Ban et al. 2016).

In addition to IRF7 and IRF5, IRF1 also interacts with MyD88 (Negishi et al. 2006). IRF1 is not involved in type I IFN gene induction in pDCs but is critical for CpG-B oligonucleotide-mediated type I IFN gene induction in conventional DCs (cDCs) (Fig. 2) (Negishi et al. 2006). IRF1 is also required for expression of proinflammatory cytokine genes in macrophages that are augmented by type II IFN. In other words, IRF1 is strongly induced by a combination of IFN- $\gamma$ and TLR signaling, which leads to the strong induction of IRF1-dependent genes such as Il12a and iNos (Negishi et al. 2006). Interestingly, IRF8 does not interact with MyD88 (Negishi et al. 2005), but is involved in the induction of type I IFN genes in TLR-stimulated pDCs (Tailor et al. 2007). Here, IRF8 binds to TRAF6 and is also involved in the activation of NF- $\kappa \mathrm{B}$ for the induction of proinflammatory cytokines (Tsujimura et al. 2004; Zhao et al. 2006).

Type I IFN Gene Induction by IRFs on Innate Recognition of Cytosolic RNA

Two RNA helicase enzymes, RIG-I and melanoma differentiation-associated gene 5 (MDA5), are essential cytosolic receptors for detection of RNA, in particular uncapped $5^{\prime}$-triphosphate RNA and dsRNA, including poly(rI:rC) (Yoneyama et al. 2005; Kato et al. 2006). Both helicases contain a carboxy terminal $\mathrm{DExD} / \mathrm{H}$ box RNA helicase domain that is responsible for detection of viral RNA, as well as two aminoterminal caspase activation and recruitment domains (CARDs) that activate downstream 
IFNs and the IRF Family

signaling pathways (Yoneyama et al. 2005). The adaptor molecule that links the sensing of viral RNA by RIG-I or MDA5 to downstream signaling is mitochondrial antiviral signaling protein (MAVS, also known as VISA, IPS-1, or Cardif) (Seth et al. 2005; Tamura et al. 2008). MAVS contains an amino-terminal CARD domain that mediates CARD-CARD interactions with
CARD domains of RIG-I and MDA5 to transmit downstream signaling. MAVS relays signals from RIG-I and MDA5 to TANK-binding kinase 1 (TBK1) and IKKe that are known to phosphorylate IRF3 and IRF7 (Fig. 3) (Kumar et al. 2006; Sun et al. 2006).

IRF3 and IRF7, two IRFs with the greatest sequence homology with one another, are essen-

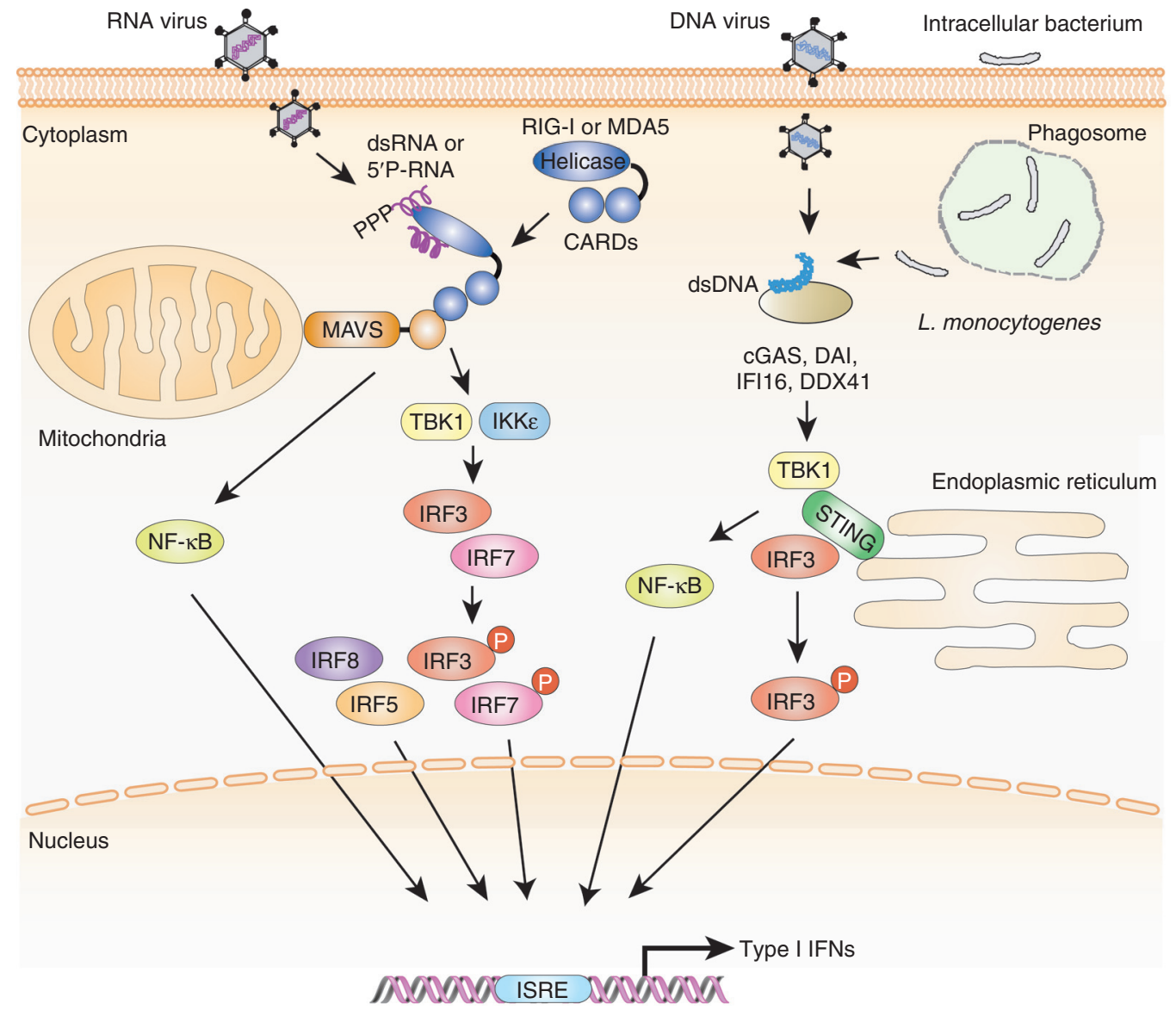

Figure 3. Schematic illustration of type I interferon (IFN) gene induction by IFN regulatory factors (IRFs) on innate recognition of cytosolic nucleic acids. Type I IFN genes, particularly IFN- $\beta$, are induced via TIR domaincontaining adaptor, including IFN- $\beta$ (TRIF) downstream of TLR3 and TLR4 signaling pathways, and via myeloid differentiation primary-response protein 88 (MyD88) downstream of TLR7 and TLR9 signaling pathways. Further, the TRIF pathway signals exclusively to IRF3 to induce IFN- $\beta$ gene expression. IRF7 may also be involved for TLR3-, but not for retinoic acid-inducible gene I (RIG-I)-like receptor (RLR)4-mediated type I IFN gene induction. In the MyD88 pathway, IRF1, IRF5, and IRF7 form a complex with MyD88. Among MyD88-bound IRFs, IRF7 is critical for the robust induction of type I IFN in plasmacytoid dendritic cells (pDCs). IRF5 is partially involved in type I IFN gene induction in pDCs, whereas IRF1 is important for expression of type I IFNs in conventional DCs (cDCs). In contrast, IRF8 is involved in the expression of type I IFN genes in pDCs, but does not bind to MyD88. IRF3 also does not bind to MyD88, but is involved in Listeria monocytogenes-mediated type I IFN gene induction in pDCs. 
H. Negishi et al.

tial for the RIG-I/MDA5-mediated type I IFN gene-induction pathway. Initially, IRF3 and IRF7 reside in latent forms in the cytosol of uninfected cells. Upon virus infection, RIGI- or MDA5-activated TBK1 phosphorylates IRF3 at Ser396, 398, 402, 404, and 405 in site 2 of the carboxy-terminal regulatory region, which alleviates autoinhibition and permits IRF3 nuclear translocation and interaction with the coactivator CBP (Servant et al. 2003; Mori et al. 2004; Honda et al. 2006; Tamura et al. 2008). Then CBP facilitates phosphorylation of Ser385 or Ser386 at site 1 within the regulatory region, permitting IRF dimerization (Mori et al. 2004; Panne et al. 2007). A similar mechanism involving IRF7 is presumed to occur. As a result, a holocomplex containing dimerized IRF3 and IRF7, either as a homodimer or heterodimer, and coactivators such as CBP or p300 is formed in the nucleus. This holocomplex binds to target ISRE DNA sequences within the promoters of type I IFN genes (Lin et al. 1998; Sato et al. 1998; Yoneyama et al. 1998; Honda et al. 2006). Additionally, IRF5 is involved in the RIG-I/MAVS signaling pathway (Yanai et al. 2007; Paun et al. 2008; Lazear et al. 2013). IRF5 translocates from the cytoplasm to the nucleus on infection by vesicular stomatitis virus (VSV) or Newcastle disease virus (NDV) (Barnes et al. 2002). Challenged with these RNA viruses, Irf $5^{-1}$ mice show a reduction in the serum levels of type I IFN (Yanai et al. 2007). Moreover, Irf5 $5^{-/-}$mice are highly vulnerable to VSV infection. Because Irf $5^{-l}$ macrophages are defective in the production of type I IFNs by VSV, whereas $\mathrm{Irf5}^{-1-}$ mouse embryonic fibroblasts (MEFs) are not (possibly because of a higher expression of IRF5 in hematopoietic cells), there is a celltype-specific requirement for IRF5 (Yanai et al. 2007; Paun et al. 2008). In addition, Irf5 ${ }^{-/-}$mice show reduced levels of proinflammatory cytokines, such as IL- 6 and TNF- $\alpha$ on virus infection (Yanai et al. 2007; Paun et al. 2008). The precise mechanism by which IRF5 is activated by RIG-I and the nature of IRF5's contribution to the transcriptional regulation of type I IFN and proinflammatory genes remains to be clarified. Nevertheless, like IRF3 and IRF7, IRF5 can also be phosphorylated by TBK1 or IKK $\beta$ to exert its transcriptional activities (Lin et al. 2005; Paun et al. 2008; Balkhi et al. 2010; Chang Foreman et al. 2012; Bergstrøm et al. 2015).

IRF8 is also required for type I IFN induction in virus-stimulated DCs (Tailor et al. 2007). It appears that IRF8 is involved in the transcriptional regulation of type I IFN genes; IRF8 binds to promoters of IFN- $\alpha / \beta$ genes and is required for the second amplifying phase of IFN transcription.

Type I IFN Gene Induction by IRFs on Innate Recognition of Cytosolic DNA

In addition to the cytosolic RNA-sensing mechanisms, attention has been focused on characterizing cytosolic DNA-sensing systems because they can also evoke protective and pathological immune responses. Cytoplasmic recognition of bacterial genomic DNA from $L$. monocytogenes results in IFN- $\beta$ induction through the TBK1IRF3 pathway (Stetson and Medzhitov 2006). The transfection of cells with synthetic dsDNA, such as poly(dA-dT).poly(dT-dA) (termed BDNA hereafter), results in the induction of type I IFN in the absence of all TLR signaling (Ishii et al. 2006). These observations indicate the presence of a cytosolic DNA sensor(s) that can independently initiate innate immune responses, including the induction of type I IFN genes. B-DNA stimulation results in the activation of IRF3 and NF- $\kappa B$ signaling pathways (Fig. 3) (Ishii et al. 2006; Tamura et al. 2008). A required role for IRF3 is seen in the observation that the B-DNA induction of IFN- $\beta$ was abolished in Irf $3^{-/-}$MEFs but normal in Irf $7^{-/}$or Irf $5^{-/-}$MEFs. The induction of IFN- $\alpha$, however, requires both IRF3 and IRF7, because both $\operatorname{Irf3} 3^{-/-}$and Irf7 ${ }^{-1-}$ MEFs showed impairment in its induction (Takaoka et al. 2007).

A candidate DNA sensor called DNA-dependent activator of IRFs (DAI), also known as DLM-1- or Z-DNA-binding protein 1 (ZBP1), has been identified and characterized (Takaoka et al. 2007). More recent studies indicate the presence of additional DNA sensors. These include cyclic CMP-AMP synthase (cGAS), IFNinducible protein 16 (IFI16)/IFN-activated gene 204 (IFI204), and (Asp-Glu-Ala-Asp) (DEAD) 
box polypeptide 41 (DDX41) (Fig. 3) (Ishikawa et al. 2009; Unterholzner et al. 2010; Zhang et al. 2011; Sun et al. 2013). In addition, an adaptor protein termed STING/mediator of IRF3 activation (MITA) has been reported (Zhong et al. 2008; Ishikawa et al. 2009). The induction of dsDNA-mediated type I IFN gene expression is markedly impaired in STING/MITA-deficient cells (Zhong et al. 2008; Ishikawa et al. 2009). STING/MITA provides a scaffold to TBK1, which phosphorylates IRF3 leading to its activation and downstream activation of type I IFN gene expression.

\section{TYPE II IFN AND IRFS IN IMMUNOLOGICAL AND INFLAMMATORY RESPONSES}

IFN- $\gamma$ is a multifunctional $34-\mathrm{kDa}$ homodimer cytokine that is the only member of the type II class of IFNs (Gray and Goeddel 1982; Naylor et al. 1983; Farrar and Schreiber 1993). Initially, it was thought that $\mathrm{CD} 4^{+} \mathrm{T}$ helper cell type 1 (Th1) lymphocytes, $\mathrm{CD}^{+}$cytotoxic lymphocytes, and NK cells exclusively produce IFN- $\gamma$ (Wheelock 1965; Gray et al. 1982; Farrar and Schreiber 1993; Schoenborn and Wilson 2007). However, recent reports provide evidence that other cells, such as B cells, NK T cells, dendritic cells, and macrophages also secrete IFN- $\gamma$. The IFN- $\gamma$ gene contains binding sites for several transcription factors in its promoter region (Glimcher et al. 2004; Schoenborn and Wilson 2007). They include AP-1, CREB/ATF, NFAT, NF- $\kappa B$, T-bet, Eomes, STATs, but not IRFs. Stimulation of cells via the T-cell receptor or with cytokines such as type I IFN, IL-12, or IL-18 induces IFN- $\gamma$ gene expression through the activation of these transcription factors (Schoenborn and Wilson 2007). IFN- $\gamma$ performs its biological functions through an IFN$\gamma$ receptor (IFNGR1/2)-mediated signal transduction pathway. The IFN- $\gamma$ receptor activation causes phosphorylation of STAT1 by the receptor-associated JAK1 and JAK2 (Farrar and Schreiber 1993; Schoenborn and Wilson 2007). Phosphorylated STAT1 forms homodimers, translocates into the nucleus, and activates several IFN- $\gamma$ response genes (IRGs) by binding to GAS motifs within their promoters (Fig. 1).
IFN- $\gamma$ stimulation induces several IRGs, including IRF1. IRF1 is critical for the IFN- $\gamma$ enhancement of a TLR-dependent gene-induction program (Negishi et al. 2006). This is underscored by the observation that $\operatorname{Irf1} 1^{-/-} \mathrm{cDCs}$ and macrophages stimulated with IFN- $\gamma$ in combination with $\mathrm{CpG}$ are impaired in their induction of genes encoding IFN- $\beta$, iNOS, and IL-12p35 (Negishi et al. 2006). Although IFN- $\gamma$ strongly induces IRF1 transcription, it is insufficient to fully activate IRF1. Rather, TLR9 engagement causes a MyD88-dependent "IRF1 licensing" event to occur in which IRF1 is posttranslationally modified to migrate into the nucleus more efficiently than non-MyD88-associated IRF1 (Negishi et al. 2006). Clarification of the modifications of IRF1 requires further investigation. Interestingly, IFN- $\gamma$ promotes Th1 and attenuates IL-4-driven Th2 responses via the induction of IRF1 and IRF2, respectively (Elser et al. 2002). In addition, IRF1 is important for apoptosis that is activated or enhanced by IFN- $\gamma$ (Kano et al. 1999; Tamura et al. 2008). The target gene(s) of IRF1 responsible for apoptotic responses have not been firmly identified, but may include genes encoding caspase- 1 , caspase-7, caspase-8, and/or TNF-related apoptosis-inducing ligand (TRAIL) (Tamura et al. 2008).

IRF8 is another member of the IRF family that is induced by IFN- $\gamma$ (Kantakamalakul et al. 1999; Ozato et al. 2007; Tamura et al. 2008). IRF8 directly contributes to the induction of numerous genes in IFN- $\gamma$-treated cells (Ozato et al. 2007; Tamura et al. 2008). Moreover, numerous genes are regulated by multiprotein complexes containing IFN- $\gamma$-induced IRF8 and other transcription factors, especially PU.1, STAT1, and, in some cases, IRF1; these genes include those encoding IL-12p40, IL-12p35, gp91phox, p67phox, TLR4, TLR9, iNOS, Fc $\gamma$ receptor I (Fc $\gamma$ RI), IRF8 itself, IL-18, CCL5/RANTES, and Nramp1 (Ozato et al. 2007; Tamura et al. 2008). In addition, IRF8 has also been reported to manifest antitumor activity. IFN- $\gamma$-induced IRF8 sensitizes human colon carcinoma cells to Fas-mediated apoptosis (Liu and Abrams 2003), and IRF8 represses the PTPN13 gene that encodes a ubiquitously expressed protein- 
H. Negishi et al.

tyrosine phosphatase, namely, Fas-associated phosphatase 1 (Huang et al. 2008).

\section{TYPE III IFN AND IRF FAMILY}

As with type I IFNs, type III IFNs are induced on the recognition of a variety of PAMPs derived from viruses (Kotenko et al. 2003; Sheppard et al. 2003; Ank et al. 2006, 2008; Durbin et al. 2013; Lazear et al. 2015; Wack et al. 2015). Although nucleic acid-sensing PRRs such as TLR3, 7/8, 9, and cGAS are known to be involved in the type III IFNs gene induction, the molecular mechanism(s) remains unclear (Odendall et al. 2014; Lazear et al. 2015). On the other hand, the molecular mechanism underlying RLR-mediated induction of type III IFN genes is well studied and involves similar signaling molecules as is the case with type I IFNs (Odendall et al. 2014; Lazear et al. 2015). However, in the control of gene transcription, there are some differences between type I and III IFNs. For the induction of the If $n b$ gene, IRFs along with AP-1 and NF- $\mathrm{KB}$ bind to the promoter region and cooperate to activate gene transcription, whereas IRF3, IRF7, and NF- $\kappa$ B, but not AP-1, are necessary for the activation of type III IFN gene transcription in spite of the existence of AP-1-binding site within the promoter regions (Osterlund et al. 2005; Onoguchi et al. 2007; Iversen and Paludan 2010; Durbin et al. 2013). Although NF- $\kappa$ B is involved, but not essential, in the transcription of type I IFN genes, type III IFN gene transcription is more dependent on NF- $\kappa \mathrm{B}$ (Iversen and Paludan 2010). In addition, IRF1 is involved in the gene induction of type III IFNs but not type I IFNs (Odendall et al. 2014). IRF1 is activated downstream of MAVS and required for expression of type III IFN only, whereas IRF3 and IRF7 are activated in both mitochondrial and peroxisomal MAVS pathways and are involved in both type I IFN and type III IFN gene induction (Siegel et al. 2011; Odendall et al. 2014). Recently, type III IFN-specific regulators targeting IRF family proteins have been reported. For instance, Med23 interacts with IRF7 and these factors synergistically augment gene expression of type III IFNs but not type I IFNs (Griffiths et al.
2013). Further, BLIMP-1 acts as a negative regulator by binding to the IRF1-binding site on the promoter of type III IFN genes (Odendall et al. 2014). IRF1-mediated type III IFN gene is also inhibited by virus-induced activation of epidermal growth factor receptor (EGFR) signaling (Ueki et al. 2013).

\section{CONCLUDING REMARKS}

Remarkable achievements have been made in the past four decades, with the demonstration of the existence of multiple IFN types and the underlying mechanisms as to how IFN genes are regulated and show multiple biological functions. In this review, we describe how three types of IFNs are regulated by the IRF family transcription factors. Clearly, the versatile function of these IFNs is of great interest, particularly in terms of the regulation of immune responses and oncogenesis (Decker et al. 2005; Tamura et al. 2008; Ivashkiv and Donlin 2014; Zitvogel et al. 2015). Of particular note, although IFN systems are basically beneficial to the host, aberrant operation of IFNs, particularly type I IFNs, is associated with autoimmunity, indicating the pathogenic aspects of the IFN system when left uncontrolled (Vilcek 2006; Trinchieri 2010).

Another interesting issue is the evolutional aspects of the IFN systems and IRFs. It is well known that the IFN systems are found only in jawed vertebrates, whereas other cytokines such as IL-17 and IL-8 are found in jawless vertebrates (Guo et al. 2009). In the oldest literature for the type I IFN family, it was concluded that IFN- $\alpha$ and $-\beta$ genes diverged about the time of the start for vertebrate evolution, which is the time when adaptive immunity involving $\mathrm{T}$ and $\mathrm{B}$ lymphocytes became operational (Taniguchi et al. 1980; Pancer and Cooper 2006). On the other hand, it has been shown that the IRF family members, along with the innate receptors such as TLRs, are found in animals other than vertebrates (Roach et al. 2005; Nehyba et al. 2009). It has been reported that the origin of the IRF family coincides with the appearance of multicellularity in animals (Nehyba et al. 2009; Yuan et al. 2015), and IRF genes are 
IFNs and the IRF Family

present in all principal metazoan groups. Interestingly, these genes are not found in the two groups that include most of metazoan species (i.e., roundworms and insects), suggesting that they disappeared during the evolution of these animals (Nehyba et al. 2009). As such, one may envisage that the IRF family members evolved first and then these factors became operational on the acquisition of the IFN system for its regulation.

In this regard, it is also interesting that the IRF family coevolved with the NF- $\mathrm{KB}$ family (Takaoka et al. 2008; Nehyba et al. 2009). It is well known that these families are critical for the metazoan organism for its host defense; therefore, these families might have coevolved as the consequence of changing selection pressure in the given environments. Of note, these family members cooperate in the gene-induction programs, often by direct interactions (Honda et al. 2006; Tamura et al. 2008; Iwanaszko and Kimmel 2015). In addition, these two families also function in reproduction and development (McDonald et al. 2006; Ozato et al. 2007). As such, these families could have been acquired during the evolution of multicellular organisms so as to cooperate to ensure effective cellar responses, in particular for host defense against external threats. On the other hand, dysregulation of these families can critically contribute to the development of oncogenesis (Karin 2006; Takaoka et al. 2008; Tamura et al. 2008). Clearly, the IRF members are less characterized compared to the NF- $\mathrm{\kappa B}$ members and further future studies are desired to reveal more detailed mechanisms on the regulation of IRF functions in the regulation of IFN responses as well as other biological processes.

\section{ACKNOWLEDGMENTS}

This work is supported in part by a Grant-InAid for Scientific Research (S) 15638461 from the Ministry of Education, Culture, Sports, Science (MEXT) and the Japan Agency for Medical Research and Development (A-MED) 15656877. The Department of Molecular Immunology is supported by BONAC Corporation and Kyowa Hakko Kirin Co., Ltd.

\section{REFERENCES}

Alexopoulou L, Holt AC, Medzhitov R, Flavell RA. 2001. Recognition of double-stranded RNA and activation of NF-кB by Toll-like receptor 3. Nature 413: 732-738.

Andersson U, Tracey KJ. 2011. HMGB1 is a therapeutic target for sterile inflammation and infection. Annu Rev Immunol 29: 139-162.

Ank N, West H, Bartholdy C, Eriksson K, Thomsen AR, Paludan SR. 2006. Lambda interferon (IFN- $\lambda$ ), a type III IFN, is induced by viruses and IFNs and displays potent antiviral activity against select virus infections in vivo. J Virol 80: 4501-4509.

Ank N, Iversen MB, Bartholdy C, Staeheli P, Hartmann R, Jensen UB, Dagnaes-Hansen F, Thomsen AR, Chen Z, Haugen $\mathrm{H}$, et al. 2008. An important role for type III interferon (IFN- $\lambda /$ IL-28) in TLR-induced antiviral activity. J Immunol 180: 2474-2485.

Balkhi MY, Fitzgerald KA, Pitha PM. 2008. Functional regulation of MyD88-activated interferon regulatory factor 5 by K63-linked polyubiquitination. Mol Cell Biol 28: 7296-7308.

Balkhi MY, Fitzgerald KA, Pitha PM. 2010. IKK $\alpha$ negatively regulates IRF-5 function in a MyD88-TRAF6 pathway. Cell Signal 22: 117-127.

Ban T, Sato GR, Nishiyama A, Akiyama A, Takasuna M, Umehara M, Suzuki S, Ichino M, Matsunaga S, Kimura A, et al. 2016. Lyn kinase suppresses the transcriptional activity of IRF5 in the TLR-MyD88 pathway to restrain the development of autoimmunity. Immunity 45: 319332.

Barnes BJ, Kellum MJ, Field AE, Pitha PM. 2002. Multiple regulatory domains of IRF-5 control activation, cellular localization, and induction of chemokines that mediate recruitment of T lymphocytes. Mol Cell Biol 22: 57215740.

Bergstrøm B, Aune MH, Awuh JA, Kojen JF, Blix KJ, Ryan L, Flo TH, Mollnes TE, Espevik T, Stenvik J. 2015. TLR8 senses Staphylococcus aureus RNA in human primary monocytes and macrophages and induces IFN- $\beta$ production via a TAK1-IKK $\beta$-IRF5 signaling pathway. J Immunol 195: 1100-1111.

Capobianchi MR, Uleri E, Caglioti C, Dolei A. 2015. Type I IFN family members: Similarity, differences and interaction. Cytokine Growth Factor Rev 26: 103-111.

Chang Foreman HC, Van Scoy S, Cheng TF, Reich NC. 2012. Activation of interferon regulatory factor 5 by site specific phosphorylation. PLoS ONE 7: e33098.

Colonna M, Trinchieri G, Liu YJ. 2004. Plasmacytoid dendritic cells in immunity. Nat Immunol 5: 1219-1226.

Decker T, Müller M, Stockinger S. 2005. The yin and yang of type I interferon activity in bacterial infection. Nat Rev Immunol 5: 675-687.

de Weerd NA, Vivian JP, Nguyen TK, Mangan NE, Gould JA, Braniff SJ, Zaker-Tabrizi L, Fung KY, Forster SC, Beddoe T, et al. 2013. Structural basis of a unique interferon- $\beta$ signaling axis mediated via the receptor IFNAR1. Nat Immunol 14: 901-907.

Durbin RK, Kotenko SV, Durbin JE. 2013. Interferon induction and function at the mucosal surface. Immunol Rev 255: 25-39. 
H. Negishi et al.

Elser B, Lohoff M, Kock S, Giaisi M, Kirchhoff S, Krammer $\mathrm{PH}, \mathrm{Li}-$ Weber M. 2002. IFN- $\gamma$ represses IL-4 expression via IRF-1 and IRF-2. Immunity 17: 703-712.

Farrar MA, Schreiber RD. 1993. The molecular cell biology of interferon- $\gamma$ and its receptor. Annu Rev Immunol 11: 571-611.

Glimcher LH, Townsend MJ, Sullivan BM, Lord GM. 2004. Recent developments in the transcriptional regulation of cytolytic effector cells. Nat Rev Immunol 4: 900-911.

Gray PW, Goeddel DV. 1982. Structure of the human immune interferon gene. Nature 298: 859-863.

Gray PW, Leung DW, Pennica D, Yelverton E, Najarian R, Simonsen CC, Derynck R, Sherwood PJ, Wallace DM, Berger SL, et al. 1982. Expression of human immune interferon cDNA in E. coli and monkey cells. Nature 295: 503-508.

Griffiths SJ, Koegl M, Boutell C, Zenner HL, Crump CM Pica F, Gonzalez O, Friedel CC, Barry G, Martin K, et al. 2013. A systematic analysis of host factors reveals a Med23-interferon- $\lambda$ regulatory axis against herpes simplex virus type 1 replication. PLoS Pathog 9: e1003514.

Guo P, Hirano M, Herrin BR, Li J, Yu C, Sadlonova A, Cooper MD. 2009. Dual nature of the adaptive immune system in lampreys. Nature 459: 796-801.

Hemmi H, Takeuchi O, Sato S, Yamamoto M, Kaisho T, Sanjo H, Kawai T, Hoshino K, Takeda K, Akira S. 2004 The roles of two IкB kinase-related kinases in lipopolysaccharide and double stranded RNA signaling and viral infection. J Exp Med 199: 1641-1650.

Hervas-Stubbs S, Perez-Gracia JL, Rouzaut A, Sanmamed MF, Le Bon A, Melero I. 2011. Direct effects of type I interferons on cells of the immune system. Clin Cancer Res 17: 2619-2627.

Hida S, Ogasawara K, Sato K, Abe M, Takayanagi H, Yokochi T, Sato T, Hirose S, Shirai T, Taki S, et al. 2000. $\mathrm{CD}^{+}$T cell-mediated skin disease in mice lacking IRF-2, the transcriptional attenuator of interferon- $\alpha / \beta$ signaling. Immunity 13: 643-655.

Honda K, Yanai H, Mizutani T, Negishi H, Shimada N, Suzuki N, Ohba Y, Takaoka A, Yeh WC, Taniguchi T. 2004. Role of a transductional-transcriptional processor complex involving MyD88 and IRF-7 in Toll-like receptor signaling. Proc Natl Acad Sci 101: 15416-15421.

Honda K, Yanai H, Negishi H, Asagiri M, Sato M, Mizutani T, Shimada N, Ohba Y, Takaoka A, Yoshida N, et al. 2005 IRF-7 is the master regulator of type-I interferon-dependent immune responses. Nature 434: 772-777.

Honda K, Takaoka A, Taniguchi T. 2006. Type I interferon gene induction by the interferon regulatory factor family of transcription factors. Immunity 25: 349-360.

Hoshino K, Sugiyama T, Matsumoto M, Tanaka T, Saito M, Hemmi H, Ohara O, Akira S, Kaisho T. 2006. IкB kinase$\alpha$ is critical for interferon- $\alpha$ production induced by Tolllike receptors 7 and 9. Nature 440: 949-953.

Huang W, Zhu C, Wang H, Horvath E, Eklund EA. 2008. The interferon consensus sequence-binding protein (ICSBP/IRF8) represses PTPN13 gene transcription in differentiating myeloid cells. J Biol Chem 283: 7921-7935.

Isaacs A, Lindenmann J. 1957. Virus interference. I: The interferon. Proc R Soc Lond B Biol Sci 147: 258-267.
Ishii KJ, Coban C, Kato H, Takahashi K, Torii Y, Takeshita F, Ludwig H, Sutter G, Suzuki K, Hemmi H, et al. 2006. A Toll-like receptor-independent antiviral response induced by double-stranded B-form DNA. Nat Immunol 7: 40-48.

Ishikawa H, Ma Z, Barber GN. 2009. STING regulates intracellular DNA-mediated, type I interferon-dependent innate immunity. Nature 461: 788-792.

Ivashkiv LB, Donlin LT. 2014. Regulation of type I interferon responses. Nat Rev Immunol 14: 36-49.

Iversen MB, Paludan SR. 2010. Mechanisms of type III interferon expression. J Interferon Cytokine Res 30: 573578.

Iwanaszko M, Kimmel M. 2015. NF-אB and IRF pathways: Cross-regulation on target genes promoter level. $B M C$ Genomics 16: 307

Kano A, Haruyama T, Akaike T, Watanabe Y. 1999. IRF-1 is an essential mediator in IFN- $\gamma$-induced cell cycle arrest and apoptosis of primary cultured hepatocytes. Biochem Biophys Res Commun 257: 672-677.

Kantakamalakul W, Politis AD, Marecki S, Sullivan T, Ozato K, Fenton MJ, Vogel SN. 1999. Regulation of IFN consensus sequence binding protein expression in murine macrophages. J Immunol 162: 7417-7425.

Karin M. 2006. Nuclear factor- $\mathrm{\kappa B}$ in cancer development and progression. Nature 441: 431-436.

Kato H, Takeuchi O, Sato S, Yoneyama M, Yamamoto M, Matsui K, Uematsu S, Jung A, Kawai T, Ishii KJ, et al. 2006. Differential roles of MDA5 and RIG-I helicases in the recognition of RNA viruses. Nature 441: 101-105.

Katze MG, He Y, Gale M Jr. 2002. Viruses and interferon: A fight for supremacy. Nat Rev Immunol 2: 675-687.

Kawai T, Akira S. 2006. TLR signaling. Cell Death Differ 13: 816-825.

Kawai T, Sato S, Ishii KJ, Coban C, Hemmi H, Yamamoto M, Terai K, Matsuda M, Inoue J, Uematsu S, et al. 2004 Interferon- $\alpha$ induction through Toll-like receptors involves a direct interaction of IRF7 with MyD88 and TRAF6. Nat Immunol 5: 1061-1068.

Knight E Jr. 1975. Heterogeneity of purified mouse interferons. J Biol Chem 250: 4139-4144.

Kotenko SV, Gallagher G, Baurin VV, Lewis-Antes A, Shen M, Shah NK, Langer JA, Sheikh F, Dickensheets H, Donnelly RP. 2003. IFN- $\lambda$ s mediate antiviral protection through a distinct class II cytokine receptor complex. Nat Immunol 4: 69-77.

Kumar H, Kawai T, Kato H, Sato S, Takahashi K, Coban C, Yamamoto M, Uematsu S, Ishii KJ, Takeuchi O, et al. 2006. Essential role of IPS-1 in innate immune responses against RNA viruses. J Exp Med 203: 1795-1803.

Lazear HM, Lancaster A, Wilkins C, Suthar MS, Huang A, Vick SC, Clepper L, Thackray L, Brassil MM, Virgin HW, et al. 2013. IRF-3, IRF-5, and IRF-7 coordinately regulate the type I IFN response in myeloid dendritic cells downstream of MAVS signaling. PLoS Pathog 9: e1003118.

Lazear HM, Nice TJ, Diamond MS. 2015. Interferon- $\lambda$ : Immune functions at barrier surfaces and beyond. Immunity 43: $15-28$.

Levy DE, Garcia-Sastre A. 2001. The virus battles: IFN induction of the antiviral state and mechanisms of viral evasion. Cytokine Growth Factor Rev 12: 143-156. 
Lin R, Heylbroeck C, Pitha PM, Hiscott J. 1998. Virus-dependent phosphorylation of the IRF-3 transcription factor regulates nuclear translocation, transactivation potential, and proteasome-mediated degradation. Mol Cell Biol 18: 2986-2996.

Lin R, Yang L, Arguello M, Penafuerte C, Hiscott J. 2005. A CRM1-dependent nuclear export pathway is involved in the regulation of IRF-5 subcellular localization. J Biol Chem 280: 3088-3095.

Liu K, Abrams SI. 2003. Coordinate regulation of IFN consensus sequence-binding protein and caspase- 1 in the sensitization of human colon carcinoma cells to Fas-mediated apoptosis by IFN- $\gamma$. J Immunol 170: 6329-6337.

Maeda S, McCandliss R, Gross M, Sloma A, Familletti PC, Tabor JM, Evinger M, Levy WP, Pestka S. 1980. Construction and identification of bacterial plasmids containing nucleotide sequence for human leukocyte interferon. Proc Natl Acad Sci 77: 7010-7013.

Mancino A, Natoli G. 2016. Specificity and function of IRF family transcription factors: Insights from genomics. $J$ Interferon Cytokine Res 36: 462-469.

McDonald DR, Janssen R, Geha R. 2006. Lessons learned from molecular defects in nuclear factor $\mathrm{\kappa B}$ dependent signaling. Microbes Infect 8: 1151-1156.

McWhirter SM, Fitzgerald KA, Rosains J, Rowe DC, Golenbock DT, Maniatis T. 2004. IFN-regulatory factor 3-dependent gene expression is defective in Tbk1-deficient mouse embryonic fibroblasts. Proc Natl Acad Sci 101: 233-238.

Medzhitov R. 2001. Toll-like receptors and innate immunity. Nat Rev Immunol 1: 135-145.

Medzhitov R, Preston-Hurlburt P, Janeway CA Jr. 1997. A human homologue of the Drosophila Toll protein signals activation of adaptive immunity. Nature 388: 394-397.

Mori M, Yoneyama M, Ito T, Takahashi K, Inagaki F, Fujita T. 2004. Identification of Ser-386 of interferon regulatory factor 3 as critical target for inducible phosphorylation that determines activation. J Biol Chem 279: 9698-9702.

Nagano Y, Kojima Y. 1958. Inhibition of vaccinia infection by a liquid factor in tissues infected by homologous virus. C R Seances Soc Biol Fil 152: 1627-1629.

Naylor SL, Sakaguchi AY, Shows TB, Law ML, Goeddel DV, Gray PW. 1983. Human immune interferon gene is located on chromosome 12. J Exp Med 157: 1020-1027.

Negishi H, Ohba Y, Yanai H, Takaoka A, Honma K, Yui K, Matsuyama T, Taniguchi T, Honda K. 2005. Negative regulation of Toll-like-receptor signaling by IRF-4. Proc Natl Acad Sci 102: 15989-15994.

Negishi H, Fujita Y, Yanai H, Sakaguchi S, Ouyang X, Shinohara M, Takayanagi H, Ohba Y, Taniguchi T, Honda K. 2006. Evidence for licensing of IFN- $\gamma$-induced IFN regulatory factor 1 transcription factor by MyD88 in Toll-like receptor-dependent gene induction program. Proc Natl Acad Sci 103: 15136-15141.

Negishi H, Yanai H, Nakajima A, Koshiba R, Atarashi K, Matsuda A, Matsuki K, Miki S, Doi T, Aderem A, et al. 2012. Cross-interference of RLR and TLR signaling pathways modulates antibacterial $\mathrm{T}$ cell responses. Nat Immunol 13: 659-666.
Nehyba J, Hrdlicková R, Bose HR. 2009. Dynamic evolution of immune system regulators: The history of the interferon regulatory factor family. Mol Biol Evol 26: 2539-2550.

Odendall C, Dixit E, Stavru F, Bierne H, Franz KM, Durbin AF, Boulant S, Gehrke L, Cossart P, Kagan JC. 2014. Diverse intracellular pathogens activate type III interferon expression from peroxisomes. Nat Immunol 15: 717-726.

Oganesyan G, Saha SK, Guo B, He JQ, Shahangian A, Zarnegar B, Perry A, Cheng G. 2006. Critical role of TRAF3 in the Toll-like receptor-dependent and -independent antiviral response. Nature 439: 208-211.

Onoguchi K, Yoneyama M, Takemura A, Akira S, Taniguchi T, Namiki H, Fujita T. 2007. Viral infections activate types I and III interferon genes through a common mechanism. J Biol Chem 282: 7576-7581.

Osterlund P, Veckman V, Sirén J, Klucher KM, Hiscott J, Matikainen S, Julkunen I. 2005. Gene expression and antiviral activity of $\alpha / b$ interferons and interleukin-29 in virus-infected human myeloid dendritic cells. J Virol 79: 9608-9617.

Ozato K, Tailor P, Kubota T. 2007. The interferon regulatory factor family in host defense: Mechanism of action. J Biol Chem 282: 20065-20069.

Pancer Z, Cooper MD. 2006. The evolution of adaptive immunity. Annu Rev Immunol 24: 497-518.

Panne D, McWhirter SM, Maniatis T, Harrison SC. 2007. Interferon regulatory factor 3 is regulated by a dual phosphorylation-dependent switch. J Biol Chem 282: 2281622822.

Paun A, Pitha PM. 2007. The IRF family, revisited. Biochimie 89: 744-753.

Paun A, Reinert JT, Jiang Z, Medin C, Balkhi MY, Fitzgerald KA, Pitha PM. 2008. Functional characterization of murine interferon regulatory factor 5 (IRF-5) and its role in the innate antiviral response. J Biol Chem 283: 1429514308.

Perry AK, Chow EK, Goodnough JB, Yeh WC, Cheng G. 2004. Differential requirement for TANK-binding kinase-1 in type I interferon responses to Toll-like receptor activation and viral infection. J Exp Med 199: 1651-1658.

Pestka S, Krause CD, Walter MR. 2004. Interferons, interferon-like cytokines, and their receptors. Immunol Rev 202: 8-32.

Platanias LC. 2005. Mechanisms of type-I- and type-II-interferon-mediated signalling. Nat Rev Immunol 5: 375386.

Roach JC, Glusman G, Rowen L, Kaur A, Purcell MK, Smith KD, Hood LE, Aderem A. 2005. The evolution of vertebrate Toll-like receptors. Proc Natl Acad Sci 102: 95779582.

Rubinstein M, Levy WP, Moschera JA, Lai CY, Hershberg RD, Bartlett RT, Pestka S. 1981. Human leukocyte interferon: Isolation and characterization of several molecular forms. Arch Biochem Biophys 210: 307-318.

Rudd BD, Smit JJ, Flavell RA, Alexopoulou L, Schaller MA, Gruber A, Berlin AA, Lukacs NW. 2006. Deletion of TLR3 alters the pulmonary immune environment and mucus production during respiratory syncytial virus infection. $J$ Immunol 176: 1937-1942.

Sakaguchi S, Negishi H, Asagiri M, Nakajima C, Mizutani T, Takaoka A, Honda K, Taniguchi T. 2003. Essential role of 
H. Negishi et al.

IRF-3 in lipopolysaccharide-induced interferon- $\beta$ gene expression and endotoxin shock. Biochem Biophys Res Commun 306: 860-866.

Samuel CE. 2001. Antiviral actions of interferons. Clin Microbiol Rev 14: 778-809.

Sato M, Tanaka N, Hata N, Oda E, Taniguchi T. 1998. Involvement of the IRF family transcription factor IRF-3 in virus-induced activation of the IFN- $\beta$ gene. FEBS Lett 425: 112-116.

Schoenborn JR, Wilson CB. 2007. Regulation of interferon- $\gamma$ during innate and adaptive immune responses. $A d v$ Immunol 96: 41-101.

Servant MJ, Grandvaux N, tenOever BR, Duguay D, Lin R, Hiscott J. 2003. Identification of the minimal phosphoacceptor site required for in vivo activation of interferon regulatory factor 3 in response to virus and doublestranded RNA. J Biol Chem 278: 9441-9447.

Seth RB, Sun L, Ea C, Chen ZJ. 2005. Identification and characterization of MAVS, a mitochondrial antiviral signaling protein that activates NF- $\mathrm{KB}$ and IRF 3. Cell 122: 669-682.

Sheppard P, Kindsvogel W, Xu W, Henderson K, Schlutsmeyer S, Whitmore TE, Kuestner R, Garrigues U, Birks C, Roraback J, et al. 2003. IL-28, IL-29 and their class II cytokine receptor IL-28R. Nat Immunol 4: 63-68.

Siegel R, Eskdale J, Gallagher G. 2011. Regulation of IFN- $\lambda 1$ promoter activity (IFN- $\lambda 1 /$ IL-29) in human airway epithelial cells. J Immunol 187: 5636-5644.

Stark GR, Kerr IM, Williams BR, Silverman RH, Schreiber RD. 1998. How cells respond to interferons. Annu Rev Biochem 67: 227-264.

Stetson DB, Medzhitov R. 2006. Recognition of cytosolic DNA activates an IRF3-dependent innate immune response. Immunity 24: 93-103.

Stockinger S, Kastner R, Kernbauer E, Pilz A, Westermayer S, Reutterer B, Soulat D, Stengl G, Vogl C, Frenz T, et al. 2009. Characterization of the interferon-producing cell in mice infected with Listeria monocytogenes. PLoS Pathog 5: e1000355.

Sun Q, Sun L, Liu HH, Chen X, Seth RB, Forman J, Chen ZJ. 2006. The specific and essential role of MAVS in antiviral innate immune responses. Immunity 24: 633-642.

Sun L, Wu J, Du F, Chen X, Chen ZJ. 2013. Cyclic GMPAMP synthase is a cytosolic DNA sensor that activates the type I interferon pathway. Science 339: 786-791.

Suzuki Y, Ysuike M, Kondo H, Aoki T, Hirono I. 2011. Molecular cloning and expression analysis of interferon regulatory factor 10 (IRF10) in Japanese flounder, Paralichthys olivaceus. Fish Shellfish Immunol 30: 67-76.

Tailor P, Tamura T, Kong HJ, Kubota T, Kubota M, Borhi P, Gabriele L, Ozato K. 2007. The feedback phase of type I interferon induction in dendritic cells requires interferon regulatory factor 8. Immunity 27: 228-239.

Takahasi K, Suzuki NN, Horiuchi M, Mori M, Suhara W, Okabe Y, Fukuhara Y, Terasawa H, Akira S, Fujita T, et al. 2003. X-ray crystal structure of IRF-3 and its functional implications. Nat Struct Biol 10: 922-927.

Takaoka A, Mitani Y, Suemori H, Sato M, Yokochi T, Noguchi S, Tanaka N, Taniguchi T. 2000. Cross talk between interferon $-\gamma$ and $-\alpha / \beta$ signaling components in caveolar membrane domains. Science 288: 2357-2360.
Takaoka A, Yanai H, Kondo S, Duncan G, Negishi H, Mizutani T, Kano S, Honda K, Ohba Y, Mak TW, et al. 2005. Integral role of IRF-5 in the gene induction programme activated by Toll-like receptors. Nature 434: 243-249.

Takaoka A, Wang Z, Choi MK, Yanai H, Negishi H, Ban T, Lu Y, Miyagishi M, Kodama T, Honda K, et al. 2007. DAI (DLM-1/ZBP1) is a cytosolic DNA sensor and an activator of innate immune response. Nature 448: 501-505.

Takaoka A, Tamura T, Taniguchi T. 2008. Interferon regulatory factor family of transcription factors and regulation of oncogenesis. Cancer Sci 99: 467-478.

Tamura T, Yanai H, Savitsky D, Taniguchi T. 2008. The IRF family transcription factors in immunity and oncogenesis. Annu Rev Immunol 26: 535-584.

Tanaka N, Kawakami T, Taniguchi T. 1993. Recognition DNA sequences of interferon regulatory factor 1 (IRF1) and IRF-2, regulators of cell growth and the interferon system. Mol Cell Biol 13: 4531-4538.

Taniguchi T. 1988. Regulation of cytokine gene expression. Annu Rev Immunol 6: 439-464.

Taniguchi T, Takaoka A. 2001. A weak signal for strong responses: Interferon- $\alpha / \mathrm{b}$ revisited. Nat Rev Mol Cell Biol 2: 378-386.

Taniguchi T, Sakai M, Fuji-Kuriyama Y, Muramatsu M, Kobayashi S, Sudo T. 1979. Construction and identification of a bacterial plasmid containing the human fibroblast interferon gene sequence. Proc Jpn Acad 55B: 464-469.

Taniguchi T, Mantei N, Schwarzstein M, Nagata S, Muramatsu M, Weissmann C. 1980. Human leukocyte and fibroblast interferons are structurally related. Nature 285: $547-549$.

Trinchieri G. 2010. Type I interferon: Friend or foe? J Exp Med 207: 2053-2063.

Tsujimura H, Tamura T, Kong HJ, Nishiyama A, Ishii KJ, Klinman DM, Ozato K. 2004. Toll-like receptor 9 signaling activates NF- $\kappa \mathrm{B}$ through IFN regulatory factor-8/IFN consensus sequence binding protein in dendritic cells. $J$ Immunol 172: 6820-6827.

Ueki IF, Min-Oo G, Kalinowski A, Ballon-Landa E, Lanier LL, Nadel JA, Koff JL. 2013. Respiratory virus-induced EGFR activation suppresses IRF1-dependent interferon $\lambda$ and antiviral defense in airway epithelium. J Exp Med 210: 1929-1936.

Unterholzner L, Keating SE, Baran M, Horan KA, Jensen SB, Sharma S, Sirois CM, Jin T, Latz E, Xiao TS, et al. 2010. IFI16 is an innate immune sensor for intracellular DNA. Nat Immunol 11: 997-1004.

Uze G, Monneron D. 2007. IL-28 and IL-29: Newcomers to the interferon family. Biochimie 89: 729-734.

Veals SA, Schindler C, Leonard D, Fu XY, Aebersold R, Darnell JE Jr, Levy DE. 1992. Subunit of an $\alpha$-interferon-responsive transcription factor is related to interferon regulatory factor and Myb families of DNA-binding proteins. Mol Cell Biol 12: 3315-3324.

Vilcek J. 2006. Fifty years of interferon research: Aiming at a moving target. Immunity 25: 343-348.

Wack A, Terczyńska-Dyla E, Hartmann R. 2015. Guarding the frontiers: The biology of type III interferons. Nat Immunol 16: 802-809.

Wang T, Town T, Alexopoulou L, Anderson JF, Fikrig E, Flavell RA. 2004. Toll-like receptor 3 mediates West 
IFNs and the IRF Family

Nile virus entry into the brain causing lethal encephalitis. Nat Med 10: 1366-1373.

Weissmann C, Weber H. 1986. The interferon genes. Prog Nucleic Acid Res Mol Biol 33: 251-300.

Wheelock EF. 1965. Interferon-like virus-inhibitor induced in human leukocytes by phytohemagglutinin. Science 149: 310-311.

Yanai H, Chen HM, Inuzuka T, Kondo S, Mak TW, Takaoka A, Honda K, Taniguchi T. 2007. Role of IFN regulatory factor 5 transcription factor in antiviral immunity and tumor suppression. Proc Natl Acad Sci 104: 3402-3407.

Yanai H, Negishi H, Taniguchi T. 2012. The IRF family of transcription factors: Inception, impact and implications in oncogenesis. Oncoimmunology 1: 1376-1386.

Yasuda K, Nündel K, Watkins AA, Dhawan T, Bonegio RG, Ubellacker JM, Marshak-Rothstein A, Rifkin IR. 2013. Phenotype and function of $B$ cells and dendritic cells from interferon regulatory factor 5-deficient mice with and without a mutation in DOCK2. Int Immunol 25: 295-306.

Yoneyama M, Suhara W, Fukuhara Y, Fukuda M, Nishida E, Fujita T. 1998. Direct triggering of the type I interferon system by virus infection: Activation of a transcription factor complex containing IRF-3 and CBP/p300. EMBO J 17: 1087-1095.
Yoneyama M, Kikuchi M, Matsumoto K, Imaizumi T, Miyagishi M, Taira K, Foy E, Loo YM, Gale M Jr, Akira S, et al. 2005. Shared and unique functions of the DExD/H-box helicases RIG-I, MDA5, and LGP2 in antiviral innate immunity. J Immunol 175: 2851-2858.

Yuan S, Zheng T, Li P, Yang R, Ruan J, Huang S, Wu Z, Xu A. 2015. Characterization of amphioxus IFN regulatory factor family reveals an archaic signaling framework for innate immune response. J Immunol 195: 5657-5666.

Zhang Z, Yuan B, Bao M, Lu N, Kim T, Liu YJ. 2011. The helicase DDX41 senses intracellular DNA mediated by the adaptor STING in dendritic cells. Nat Immunol 12: 959-965.

Zhao J, Kong HJ, Li H, Huang B, Yang M, Zhu C, Bogunovic M, Zheng F, Mayer L, Ozato K, et al. 2006. IRF-8/interferon (IFN) consensus sequence-binding protein is involved in Toll-like receptor (TLR) signaling and contributes to the cross-talk between TLR and IFN- $\gamma$ signaling pathways. J Biol Chem 281: 10073-10080.

Zhong B, Yang Y, Li S, Wang YY, Li Y, Diao F, Lei C, He X, Zhang L, Tien P, et al. 2008. The adaptor protein MITA links virus-sensing receptors to IRF3 transcription factor activation. Immunity 29: 538-550.

Zitvogel L, Galluzzi L, Kepp O, Smyth MJ, Kroemer G. 2015. Type I interferons in anticancer immunity. Nat Rev Immunol 15: 405-414. 


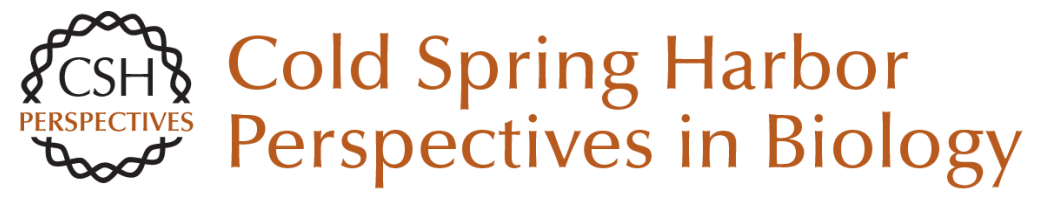

\section{The Interferon (IFN) Class of Cytokines and the IFN Regulatory Factor (IRF) Transcription Factor Family}

Hideo Negishi, Tadatsugu Taniguchi and Hideyuki Yanai

Cold Spring Harb Perspect Biol 2018; doi: 10.1101/cshperspect.a028423 originally published online September 29, 2017

\section{Subject Collection Cytokines}

Interleukin (IL)-33 and the IL-1 Family of Cytokines

--Regulators of Inflammation and Tissue

Homeostasis

Ajithkumar Vasanthakumar and Axel Kallies

Targeting IL-10 Family Cytokines for the Treatment of Human Diseases

Xiaoting Wang, Kit Wong, Wenjun Ouyang, et al.

\section{Cytokine-Mediated Regulation of CD8 T-Cell} Responses During Acute and Chronic Viral Infection

Masao Hashimoto, Se Jin Im, Koichi Araki, et al.

Cytokines in Cancer Immunotherapy

Thomas A. Waldmann

The Tumor Necrosis Factor Family: Family Conventions and Private Idiosyncrasies David Wallach

The Interferon (IFN) Class of Cytokines and the IFN Regulatory Factor (IRF) Transcription Factor Family

Hideo Negishi, Tadatsugu Taniguchi and Hideyuki Yanai
Interferon $\gamma$ and Its Important Roles in Promoting and Inhibiting Spontaneous and Therapeutic Cancer Immunity

Elise Alspach, Danielle M. Lussier and Robert D. Schreiber

Inflammasome-Dependent Cytokines at the Crossroads of Health and Autoinflammatory Disease

Hanne Van Gorp, Nina Van Opdenbosch and Mohamed Lamkanfi

Innate Lymphoid Cells (ILCs): Cytokine Hubs

Regulating Immunity and Tissue Homeostasis Maho Nagasawa, Hergen Spits and Xavier Romero Ros

T Helper Cell Differentiation, Heterogeneity, and

Plasticity Jinfang Zhu

Development, Diversity, and Function of Dendritic

Cells in Mouse and Human

David A. Anderson III, Kenneth M. Murphy and Carlos G. Briseño

Cytokines and Long Noncoding RNAs Susan Carpenter and Katherine A. Fitzgerald

For additional articles in this collection, see http://cshperspectives.cshlp.org/cgi/collection/

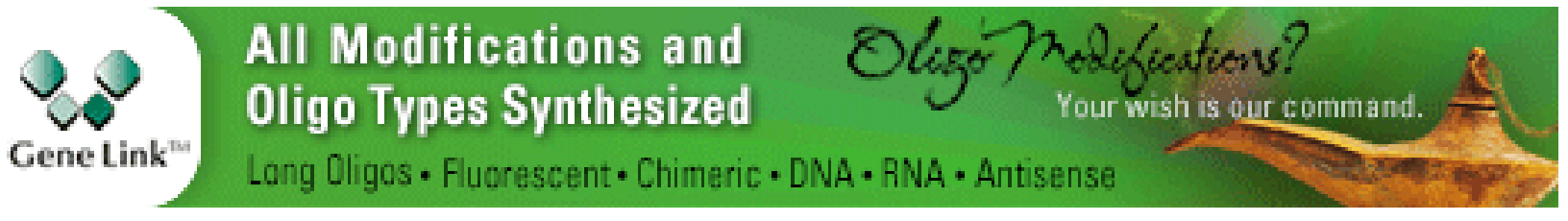


Role of the $\beta$ Common $(\beta \mathrm{c})$ Family of Cytokines in Health and Disease

Timothy R. Hercus, Winnie L. T. Kan, Sophie E. Broughton, et al.

Interleukin (IL)-12 and IL-23 and Their Conflicting Roles in Cancer Juming Yan, Mark J. Smyth and Michele W.L. Teng
Negative Regulation of Cytokine Signaling in Immunity

Akihiko Yoshimura, Minako Ito, Shunsuke Chikuma, et al.

Cancer Inflammation and Cytokines

Maria Rosaria Galdiero, Gianni Marone and Alberto Mantovani

For additional articles in this collection, see http://cshperspectives.cshlp.org/cgi/collection/

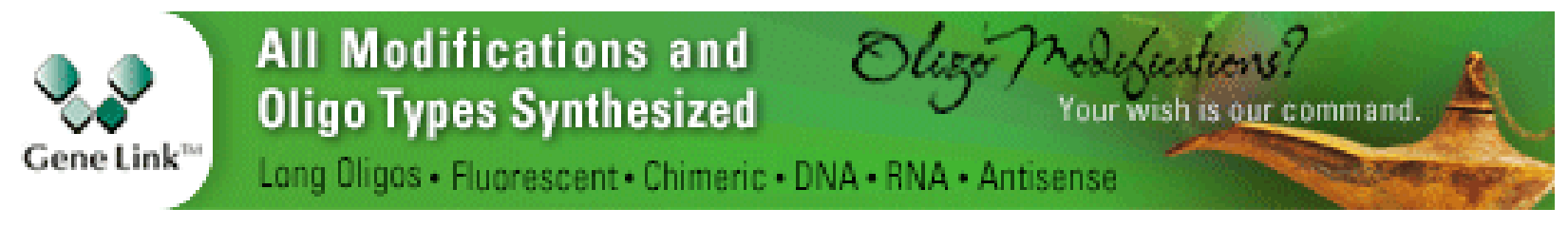

Copyright @ 2018 Cold Spring Harbor Laboratory Press; all rights reserved 